\title{
Role of biochemistry, cytology, and biopsy in the etiological diagnosis of pleural effusion- a clinical study
}

\author{
Bedi M. ${ }^{1 *}$, Joshi N. ${ }^{2}$
}

DOI: https://doi.org/10.17511/ijmrr.2020.i03.07

\footnotetext{
1* Manan Bedi, Postgraduate Resident, Department of Respiratory Medicine, NIMS University, Jaipur, Rajasthan, India.

2 Nalin Joshi, Professor, Department of Respiratory Medicine, NIMS University, Jaipur, Rajasthan, India.
}

Introduction: Pleural effusion is the most common pleural disorder. It refers to excessive or abnormal accumulation of fluid in the pleural space. It is a commonly occurring medical problem caused by various pathological conditions. To treat patients appropriately, it is important to establish an accurate etiological diagnosis. Material and Method: This is an observational study conducted at a tertiary health care center. The pleural effusion was assessed clinically, biochemically, bacteriologically, cytologically, and histopathologically. Result: Tuberculosis was the most common etiology, followed by malignancy. A pleural biopsy was done in 70 patients. Pleural tissue was obtained in 65 cases. On histopathology,Malignancy was diagnosed in 15, tuberculosis in 35, and non-specific inflammation in 13 cases. Out of 35 histological proven tuberculosis cases, 26 cases had adenosine de-aminase (ADA) more than $70 \mathrm{u} /$ l.Conclusion: Every pleural effusion is not due to tuberculosis but can be due to other causes, malignancy should always be excluded. Pleural fluid cytology and biopsy can give a definite diagnosis in a significant number of cases of pleural effusion. Tuberculosis is still the most common cause of pleural effusion followed by malignancy.

Keywords: Pleural fluid, Pleural biopsy, Tubercular, Malignancy

Corresponding Author

Manan Bedi, Postgraduate Resident, Department of Respiratory Medicine, NIMS University, Jaipur, Rajasthan, India.

Email: drmanubedi5989@gmail.com
How to Cite this Article

To Browse

Bedi M, Joshi N. Role of biochemistry, cytology, and biopsy in the etiological diagnosis of pleural effusiona clinical study. Int J Med Res Rev. 2020;8(3):259264.

Available From

https://ijmrr.medresearch.in/index.php/ijmrr/article/ view/1196

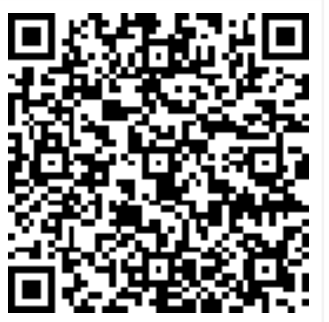

Manuscript Received 2020-05-22

Conflict of Interest No (c) 2020 by Manan Bedi, Nalin Joshi and Published by Siddharth Health Research and Social Welfare Society. This is an Open
Access article licensed under a Creative Commons Attribution 4.0 International License https://creativecommons.org/licenses/by/4.0/ unported [CC BY 4.0].

Accepted 2020-06-08 \begin{tabular}{l} 
2020-05-28 \\
\hline
\end{tabular} 2020-05-28 unding ( 


\section{Introduction}

Pleural effusionis the most common pleural disorder. It refers to excessive or abnormal accumulation of fluid in the pleural space. It is a commonly occurring medical problem caused by various pathological conditions. Pleural effusion is commonly encountered by clinicians and accounts for approximately $4 \%$ of attendance to clinics [1].

However, it often presents a diagnostic dilemma, as in about $19 \%$ cases, no cause may be found, in spite of careful evaluation [2]. To treat patientsappropriately, it is important to establish an accurate etiological diagnosis.

After routine and radiological investigations, patients who have clinically significant pleural effusion undergo thoracocentesis. Further evaluation of fluid is carried out on the basis of fluid nature i.e. if it is transudate or exudates (according to Light's Criteria) [3].

Whenever a diagnostic thoracentesis reveals an exudative effusion; more often in developing countries like India, anti-tubercular therapy is initiated.

This study was done to determine the etiology of pleural fluid by analysis of history, clinical presentation, biochemical, cytological, histopathological, and bacteriological methods. And also to perform the pleural biopsy were indicated to reach an etiological diagnosis.

Also in this study etiology was corroborated with the levels of ADA (Adenosine deaminase) in pleural fluid and then the result was analyzed.

\section{Material and Method}

This study was carried out in the Department of Respiratory Medicine at a tertiary care hospital. This study was an observational study done in a period of one year from January 2019 to December 2019. In this study, 80 patients were included.

Inclusion criteria:All patients who were willing to give informed consent, age more than 18 years, and Chest X-ray showing evidence of pleural effusion were included in this study.

Exclusion criteria:All patients who are below 18 years, not giving consent, bleeding diathesis, not able to understand language were excluded from this study.
Data collection procedure: In this study total 80 patients were included of adult age and both sex All patients underwent detailed clinical examination and laboratory examination like a blood test for hemoglobin, total WBC count, differential WBC Count, Erythrocyte Sedimentation Rate, Random Blood Sugar, RFTs, S. Proteins, serum LDH, Urine Examination, Sputum Examination, and Tuberculin Test.

Biochemical parameters of pleural fluid were determined using a selective discrete multichannel analyzer. Total protein concentration $(\mathrm{g} / \mathrm{dl})$, Lactate dehydrogenase (LDH), ADA level were measured by autoanalyzer using Biuret method (Technicon RA 1000), modified IFCC (International federation of clinical chemistry) method (Technicon RA 1000)and colorimetric endpoint method described by Guisti and Galanti (Microlab300, Merck, Netherland) respectively. Light's criteria were used to distinguish exudates from transudates [4].

Two chest X-ray PA view were taken, one prior to thoracocentesis and another after thoracocentesis to rule out complications. Ultrasound and CT scan were done whenever indicated. The pleural fluid was analyzed for cell count and type, specific gravity, protein, and sugar content and for the presence of acid-fast bacilli, other bacterial organisms and malignant cells, LDH, and ADA levels.

Pleural biopsy was done in all patients with exudative pleural effusion after taking consent, using Abram's pleural biopsy needle. Biopsies were sent for histopathological and microbiological (Z-N stain) examination for tuberculosis.

Effusions were considered to be tubercular if the pleural fluid was positive for acid-fast bacilli (AFB) by $\mathrm{Z}-\mathrm{N}$ staining or pleural biopsy specimen revealed typical epitheloid granuloma consistent with tuberculosis (TB) [3]. A serum ADA level of $>40 \mathrm{u} / \mathrm{l}$ was taken as a cut-off value for the diagnosis of tuberculosis [1].

Parapneumonic effusions were diagnosed when an acute febrile illness along with purulent sputum, leucocytosis, and pulmonary infiltrates in chest $X$ ray was present, in the absence of malignancy or other disease-causing transudates.4the levels of ADA in pleural fluid and histopathology of pleural tissue were analyzed.

The diagnosis was made on clinical examination, radiological examination, and analysis of laboratory and histopathological data.The study was been 
Conducted after approval from the ethical committee and written consent were been taken before pleural biopsy from all patients. All the results were analyzed and put in excel form and statistical analysis was done by using software SPSS

\section{Result}

In this study total, 80 patients were included under the Department of respiratory medicine.

Most of the patient was of younger age group 21-30 years $(31.25 \%)$ with most preponderance for males $(73.75 \%)$

Table-1:Age and sex distribution of pleural effusion cases.

\begin{tabular}{|l|l|l|l|l|}
\hline $\begin{array}{c}\text { Age } \\
\text { group(years) }\end{array}$ & \multicolumn{1}{|c|}{$\begin{array}{c}\text { Male } \\
\text { cases }\end{array}$} & \multicolumn{1}{|c|}{$\begin{array}{c}\text { Female } \\
\text { cases }\end{array}$} & $\begin{array}{c}\text { Total } \\
\text { cases }\end{array}$ & \multicolumn{1}{|c|}{$\begin{array}{c}\text { Percentage } \\
(\%)\end{array}$} \\
\hline $18-20$ & 5 & 2 & 7 & 8.75 \\
\hline $21-30$ & 19 & 6 & 25 & 31.25 \\
\hline $31-40$ & 15 & 5 & 20 & 25 \\
\hline $41-50$ & 5 & 4 & 9 & 11.25 \\
\hline $51-60$ & 7 & 3 & 10 & 12.5 \\
\hline$>60$ & 8 & 1 & 9 & 11.25 \\
\hline Total & 59 & 21 & 80 & 100 \\
\hline
\end{tabular}

Most of the patient was of tubercular etiology $(50.0 \%)$, followed by malignancy $(25 \%)$ as depicted in Table 2.

Table-2:Distribution of cases of pleural effusion.

\begin{tabular}{|l|l|l|}
\hline \multicolumn{1}{|c|}{ Diagnosis } & Number of cases & Percentage \\
\hline Tubercular & 40 & 50.0 \\
\hline Malignancy & 20 & 25.0 \\
\hline Parapneumonic & 10 & 12.5 \\
\hline Empyema & 5 & 6.25 \\
\hline Systemic sclerosis & 2 & 2.5 \\
\hline Congestive cardiac failure & 2 & 2.5 \\
\hline Hepatic hydrothorax & 1 & 1.25 \\
\hline Total & 80 & 100 \\
\hline
\end{tabular}

The most common symptom was cough followed by breathlessness and chest pain.

Pleural effusions were classified as:-

Mild: when fluid occupied $<1 / 3$ of hemithorax in CXR-PA view

Moderate: when fluid occupied $>1 / 3$ to $2 / 3$ of hemithorax in CXR- PA view

Massive: when fluid occupied $>2 / 3$ of hemithorax in CXR-PA
Table-3: Incidence of various symptoms.

\begin{tabular}{|l|l|l|l|l|l|l|}
\hline \multicolumn{1}{|c|}{ Diagnosis } & $\begin{array}{c}\text { Chest } \\
\text { pain }\end{array}$ & $\begin{array}{r}\text { Breathlessn } \\
\text { ess }\end{array}$ & $\begin{array}{c}\text { Cou } \\
\text { gh }\end{array}$ & $\begin{array}{c}\text { Fev } \\
\text { er }\end{array}$ & $\begin{array}{c}\text { Weight } \\
\text { loss }\end{array}$ & $\begin{array}{l}\text { Hemopty } \\
\text { sis }\end{array}$ \\
\hline Tubercular & 20 & 31 & 40 & 21 & 10 & 2 \\
\hline Malignancy & 15 & 12 & 15 & 6 & 3 & 5 \\
\hline Parapneumonic & 4 & 8 & 7 & 8 & 0 & 2 \\
\hline Empyema & 4 & 3 & 4 & 2 & 0 & 0 \\
\hline Systemic sclerosis & 1 & 0 & 1 & 2 & 0 & 0 \\
\hline $\begin{array}{l}\text { Congestive cardiac } \\
\text { failure }\end{array}$ & 2 & 2 & 1 & 1 & 0 & 0 \\
\hline Hepatic hydrothrax & 0 & 1 & & & & \\
\hline Total & 46 & 57 & 69 & 40 & 13 & 9 \\
\hline Percentage (\%) & $46 \%$ & $57 \%$ & $69 \%$ & $40 \%$ & $13 \%$ & $9 \%$ \\
\hline
\end{tabular}

The majority of tubercular effusion was moderate, while in malignancy it was found massive effusion (Table 4).

Table-4: Size of pleural effusion in different etiology.

\begin{tabular}{|l|l|l|l|}
\hline \multicolumn{1}{|c|}{ Diagnosis } & Mild & Moderate & Massive \\
\hline Tubercular & 10 & 25 & 5 \\
\hline Malignancy & 3 & 7 & 10 \\
\hline Parapneumonic & 2 & 7 & 1 \\
\hline Empyema & 0 & 3 & 2 \\
\hline Systemic sclerosis & 1 & 1 & 0 \\
\hline Congestive cardiac failure & 1 & 1 & 0 \\
\hline Hepatic hydrothorax & 0 & 1 & 0 \\
\hline Total & 17 & 45 & 18 \\
\hline Percentage (\%) & $17 \%$ & $45 \%$ & $18 \%$ \\
\hline
\end{tabular}

Table-5: General appearance of pleural effusion.

\begin{tabular}{|l|l|l|l|}
\hline \multicolumn{1}{|c|}{ Diagnosis } & Clear & Turbid & Haemorrhagic \\
\hline Tubercular & 35 & 1 & 4 \\
\hline Malignancy & 11 & 0 & 9 \\
\hline Parapneumonic & 6 & 0 & 4 \\
\hline Empyema & 0 & 5 & 0 \\
\hline Systemic sclerosis & 2 & 0 & 0 \\
\hline Congestive heart failure & 2 & 0 & 0 \\
\hline Hepatic hydrothorax & 1 & 0 & 0 \\
\hline Total & 57 & 6 & 17 \\
\hline
\end{tabular}

$54.83 \%$ of patients of tuberculous effusion, 24.19 $\%$ patients of malignant effusion, and $12.9 \%$ of patients of parapneumonic effusion had pleural fluid protein $>3 \mathrm{gm} \%$.

In congestive heart failure, systemic sclerosis, and hepatic hydrothorax all $(100 \%)$ patients had pleural fluid protein $<3 \mathrm{gm} \%$ (Table 6 ). 
Table 6:- Protein level in pleural effusion.

\begin{tabular}{|l|l|l|}
\hline \multicolumn{1}{|c|}{ Diagnosis } & Protein level <3gm\% & Protein level >3 $\mathbf{g m} \%$ \\
\hline Tubercular & 6 & 34 \\
\hline Malignancy & 5 & 15 \\
\hline Parapneumonic & 2 & 8 \\
\hline Empyema & 0 & 5 \\
\hline Systemic sclerosis & 2 & 0 \\
\hline Congestive cardiac failure & 2 & 0 \\
\hline Hepatic hydrothorax & 1 & 0 \\
\hline Total & 18 & 62 \\
\hline
\end{tabular}

Table 7:-LDH, Glucose, and ADA level in pleural fluid.

\begin{tabular}{|l|l|l|l|l|l|l|}
\hline \multirow{2}{*}{ Diagnosis } & \multicolumn{2}{|c|}{ LDH (IU) } & \multicolumn{2}{c|}{ Glucose (mg/dI) } & \multicolumn{2}{c|}{ ADA (IU) } \\
\cline { 2 - 8 } & $<200$ & $>200$ & $<60$ & $<200$ & $<200$ & $<60$ \\
\hline Tubercular & 8 & 32 & 5 & 35 & 4 & 36 \\
\hline Malignancy & 3 & 17 & 2 & 18 & 14 & 6 \\
\hline Parapneumonic & 1 & 9 & 4 & 6 & 4 & 6 \\
\hline Empyema & 0 & 5 & 5 & 0 & 0 & 5 \\
\hline Systemic sclerosis & 1 & 1 & 0 & 2 & 0 & 2 \\
\hline Congestive heart failure & 0 & 2 & 0 & 2 & 2 & 0 \\
\hline Hepatic hydrothorax & 0 & 1 & 0 & 1 & 1 & 0 \\
\hline Total & 13 & 67 & 16 & 64 & 25 & 55 \\
\hline
\end{tabular}

Table 8:- Pleural fluid cellular analysis.

\begin{tabular}{|l|l|l|l|l|l|}
\hline \multirow{2}{*}{ Diagnosis } & \multicolumn{3}{c|}{ WBC per cubic ml } & \multicolumn{2}{c|}{ Predominant cell } \\
\cline { 2 - 6 } & $0-250$ & $250-1000$ & $>1000$ & Lymphocyte & Polymorph \\
\hline Tubercular & 5 & 10 & 25 & 37 & 3 \\
\hline Malignancy & 4 & 10 & 6 & 17 & 3 \\
\hline Parapneumonic & 1 & 2 & 7 & 1 & 9 \\
\hline Empyema & 0 & 1 & 4 & 0 & 5 \\
\hline Syatemic sclerosis & 0 & 0 & 2 & 0 & 2 \\
\hline Congestive heart failure & 0 & 2 & 0 & 0 & 2 \\
\hline Hepatic hydrothorax & 0 & 0 & 1 & 0 & 1 \\
\hline Total & 10 & 25 & 45 & 56 & 25 \\
\hline
\end{tabular}

Table 9: Pleural biopsy $(n=70)$.

\begin{tabular}{|l|l|l|l|l|l|l|}
\hline Diagnosis & $\begin{array}{c}\text { Pleural } \\
\text { cytology }\end{array}$ & $\begin{array}{l}\text { Pleural Biopsy } \\
\text { histo } \\
\text { pathology }\end{array}$ & $\begin{array}{c}\text { ADA } \\
\text { (IU) } \\
<40\end{array}$ & $\begin{array}{l}\text { ADA } \\
\text { (IU) } \\
40-70\end{array}$ & $\begin{array}{l}\text { ADA } \\
\text { (IU) }\end{array}$ & $\begin{array}{l}\text { (\%) } \\
\text { Tubercular }\end{array}$ \\
\hline 40 & 35 & 0 & 9 & 26 & $\begin{array}{l}50.0 \\
\%\end{array}$ \\
\hline Malignancy & 20 & 17 & 14 & 3 & 0 & $\begin{array}{l}24.35 \\
\%\end{array}$ \\
\hline $\begin{array}{l}\text { Chronic } \\
\text { nonspecific } \\
\text { inflammation }\end{array}$ & - & 13 & 3 & 10 & 0 & $\begin{array}{l}18.5 \\
\%\end{array}$ \\
\hline $\begin{array}{l}\text { Inadequate } \\
\text { biopsy } \\
\text { specimen }\end{array}$ & - & 5 & 1 & 3 & 1 & $\begin{array}{l}7.15 \\
\%\end{array}$ \\
\hline
\end{tabular}

Pleural biopsy was taken in 70 cases only as 10 cases did not give consent. Out of which in only 65
Cases pleural tissue was obtained. 35 cases proved to be of tubercular etiology and 17 were of malignant. Pleural tissue for acid-fast stain was positive in 20 cases $(57.14 \%)$. Histopathologically tubercular granuloma was found in all tubercular cases. When the histopathological findings of these cases were correlated with ADA level, then among all the histopathologically proved tuberculosis patients and malignancy patients, 9 and 3patients had ADA level between 40-70U/L respectively.

A total of 27 patients had ADA level $\geq 70 \mathrm{U} / \mathrm{L}$ of which 26 had histopathologically proved tuberculosis and in the rest one patient, pleural biopsy tissue could not be obtained. None of the tuberculosis cases had ADA level below $40 \mathrm{U} / \mathrm{L}$. 20 patients with $A D A$ level < $40 \mathrm{U} / \mathrm{L}$ were found, 14 were histopathologically proved to be malignant. Out of 17 cases of malignancy, 14 patients had ADA level below $40 \mathrm{U} / \mathrm{L}$ and only 3 patients had ADA level in the range between 40-70 U/L (Table 9). Maximum cases of chronic non-specific inflammation showthe ADA level between 40-70 U/L.

\section{Discussion}

The current studyobserved the causative and laboratory profile of patients of pleural effusion. Tubercular pleural effusion was seen in $40 \%$ of the cases which can be due to the high prevalence of tuberculosis in India [5]. Malignant pleural effusion was seen in $20 \%$ while parapneumonic pleural effusion in $10 \%$.

Most patients belonged to the 21-30 years age group. Male: Female was 2.8:1. In this study cough and breathlessness followed by chest pain and fever were the common symptoms. Out of 40 patients of tuberculous pleural effusion, the majority $25 \%$ had moderate fluid, while patients with malignant effusion had $(10 \%)$ massive fluid. In malignant pleural effusion $85 \%$ and $3.75 \%$ had lymphocytic and polymorph predominance respectively.

In the present study, $7.5 \%$ of the tuberculous patients had polymorphic predominance. It has been shown that polymorphs predominance in TB might be because of the too early or acute stage of illness or due to secondary infection [5]. In the present study, $41.67 \%$ of patients with malignant pleural effusion had pleural fluid cytology positive for malignant cells.

In the present study male: female ratio is $2.8: 1$, which is similar to a study done by Reddy et al [6]. In this study, $71.4 \%$ of histopathologically proven 
Tubercular pleural effusion cases presented with chest pain, dry cough, breathlessness, and fever which correlates well with the previous studies $(75 \%) \quad[7,8]$. Chernow B et al. observed breathlessness as the commonest symptom (30\%) in cases of malignant pleural effusion [8] but the present study reveals chest pain and cough to be the commonest symptoms followed by fever and breathlessness [9].

Yam LT et al have shown that predominant lymphocytes in the pleural fluid are suggestive of either tuberculosis or malignancy in the majority of cases [10]. In the present study, $92.5 \%$ and $85 \%$ of diagnosed tuberculosis and malignancy patients respectively had predominant lymphocytes in their pleural fluid. Morrone $\mathrm{N}$ and Algranti $\mathrm{E}$ et al. performed pleural biopsy in 55 cases of pleural effusion and they found $43.6 \%$ cases were due to tuberculosis [11]. In a study done by Verma et al [12] it was found that of the 50 patients of pleural effusion, 19(38\%) were diagnosed as tuberculosis by pleural biopsy. Mungal et al. found in his study of 55 cases in which malignancy was proved histopathologically in $47.3 \%$ cases [13]. In another study done by Thiruvengadan et al [14], pleural biopsy established the etiology of pleural effusion as tuberculosis and malignancy in 31.1 and $22.4 \%$ of cases respectively $[15,16]$. A study done by Pandit et al [17] showed tuberculosis and malignancy by pleural biopsy in $90.9 \%$ and $63.2 \%$ of cases respectively. A study done in Bangladesh by Ahmed et al [18] showed tuberculosis and malignancy in $29.4 \%$ and $19.6 \%$ cases respectively.In another study done by Mishra et al [19], they found $79.3 \%$ and $71.4 \%$ cases respectively of malignant and tubercular etiology. In the present study, a pleural biopsy was done in 30 patients of whom 19 were tubercular $(63.3 \%)$ and 4 were malignant histopathologically (13.33\%). Pleural fluid ADA level above $70 \mathrm{U} / \mathrm{L}$ is highly suggestive of tuberculous pleuritis whereas pleural fluid ADA level below 40 $\mathrm{U} / \mathrm{L}$ rules out the diagnosis of tuberculosis as shown in a study done by Light et al [3]. This study has a limitation as it was conducted at one center only with limited data, so further studies should be done at multi centers and data then analyze to obtain more accurate results and a better understanding of the etiology.

\section{Conclusion}

In our country, every pleural effusion is not due to tuberculosis but can be due to other causes, mali-
Gnancy should always be excluded.Pleural fluid cytology and biopsy can give a definite diagnosis in a significant number of cases of pleural effusion. When the Pleural fluid ADA level is $\geq 70 \mathrm{U} / \mathrm{L}$, it can be considered as a diagnostic of tuberculosis and ADA level $<40 \mathrm{U} / \mathrm{L}$ excludesthe diagnosis of tuberculosis. Tuberculosis is still the most common cause of pleural effusion followed by malignancy.

\section{What does the study add to the existing knowledge}

This study helps in identifying the cause of pleural effusion and indicated tuberculosis as the main etiology followed by malignancy.

Clinical Implications- Pleural effusion etiology should be diagnosed properly by using various laboratory methods and biopsy if needed. A pleural biopsy might be an investigation of choice in undiagnosed cases.

\section{Author's contribution}

\section{Dr. Manan Bedi: Concept, study design \\ Dr. Nalin Joshi: Preparation of the manuscript}

\section{Reference}

01. Light RW. Pleural diseases, 6th ed. PhiladelphiaLippincott Williams \& Wilkins. 2013.

[Crossref]

02. Storey DD, Dines DE, Coles DT. Pleural effusion, A diagnostic dilemma. JAMA. 1976;236(19)2183-2186.

doi: [Article][Crossref]

03. Light RW. Approach to the patient- In pleural diseases. Lippincort Williams and Wilkings. 4th ed,2001;pp; 182-195.

[Crossref]

04. Light RW. Disorders of the pleura, mediastinum, diaphragm and chest wall, In Harrisons Principles of Internal Medicine. 16th ed, McGraw-Hill. 2005, p-1566.

[Crossref]

05. Choi H, Chon HR, Kim K, Kim S, Oh KJ, Jeong $\mathrm{SH}$, et al. Clinical and laboratory differences between lymphocyte-and neutrophilpredominant pleural tuberculosis. PLoS One. $2016 ; 11(10)$ e0165428.

doi: [Article] [Crossref] 
06. Reddy DJ, Indira C. Needle biopsy of parietal pleura in the etiological diagnosis of pleural effusion. J Indian Med Assoc. 1963;40;6-7.

[Crossref]

07. Pandit S, Chaudhuri AD, Datta SB, Dey A, Bhanja $P$. Role of pleural biopsy in etiological diagnosis of pleural effusion. Lung India. $2010 ; 27(4) 202-204$.

Available from: [Article] [Crossref]

08. Chernow B, Sahn SA. Carcinomatous involvement of pleural - an analysis of 96 pateints. Am J Med. 1977;63(5)695-702. doi: [Article] [Crossref]

09. Berger HW, Mejia E. Tuberculous pleurisy. Chest. 1973;63(1)88-92.

doi: [Article] [Crossref]

10. Yam LT. Diagnostic significance of lymphocytes in pleural effusion. Ann Intern Med. $1967 ; 66(5) 972-982$. doi: [Article] [Crossref]

11. Morrone N, Algranti E. Pleural biopsy with Cope and Abrahm's needles. Chest. 1987;92(6)10501052.

doi: [Article] [Crossref]

12. Verma S, Dubey A, Singh B. Efficacy and safety of pleural biopsy in aetiological diagnosis of pleural effusion. Int J Inf Dis. $2009 ; 7 ; 1$. [Crossref]

13. Mungal IP, Cowen PN. Multiple Pleural biopsy with Abram's needle. Thorax. 1980;35(8)600602.

doi: [Article] [Crossref]
14. Thiruvengadan KV, Anguli VC, Madanagopalan N. Etiological diagnosis of pleural effusion by punch biopsy of the parietal pleura. Chest. $1962 ; 42(5) 529-533$.

doi: [Article] [Crossref]

15. Mangaraj M. Pleural fluid MDA and serumeffusion albumin gradient in pleural effusion. Indian J Clin Biochem. 2008;23;81-84. doi: [Article] [Crossref]

16. Guisti G, Galanti B. Adenosine deaminase, InBergmeyer $\mathrm{HU}$, editor, Methods of enzyme analysis. 3rd ed, New York- Academic Press. 1983; pp-315-323.

[Crossref]

17. Biswas B, Sharma SK, Negi RS, Gupta N, Jaswal VM, Niranjan N. Pleural effusion- Role of pleural fluid cytology, adenosine deaminase level, and pleural biopsy in diagnosis. J Cytol. 2016;33(3)159-162.

Available from: [Article] [Crossref]

18. Ahmed JU, Hossain MD, Afroz F, Rahim MA, Musa AKM. Role of pleural biopsies in the etiological diagnosis of exudative pleural effusion. Bangladesh Crit Care J. 2017;5(1)3336.

doi: [Article] [Crossref]

19. Mishra AK, Verma SK, Kant S, Kushwaha RA, Garg R, Kumar S, Prakash V, Verma A, Sagar M. A study to compare the diagnostic efficacy of closed pleural biopsy with that of the thoracoscopic guided pleural biopsy in patients of pleural effusion. South Asian J Cancer. 2016;5(1)27-28. doi: [Article] [Crossref] 